\title{
Peran Komunikasi Pimpinan Terhadap Bawahan Dalam Meningkatkan Pelayanan Prima (Studi Pada Badan Pelayanan Perizinan Terpadu Kota Banjarbaru Provinsi Kalimantan Selatan)
}

\section{The Role Of Communication From The LeaderTo The Subordinates In Improving The Service Excellence (A Study At The Integrated Licensing Service Agencyln Banjarbaru City Of South Kalimantan Province)}

\author{
Emma Dienovyna ${ }^{1}$, Bambang Dwi Prasetyo, Darsono Wisadirana \\ Jurusan Ilmu Komunikasi, Program Pascasarjana, Fakultas Ilmu Sosial Dan Ilmu Politik, Universitas Brawijaya, Malang
}

\begin{abstract}
Abstrak
Pelayanan publik kebanyakan masih dianggap kurang memuaskan, sedangkan pada Badan Pelayanan Perizinan Terpadu berhasil menjadi pembeda dari organisasi publik kebanyakan. Beberapa penghargaan yang diterima menunjukkan hasil dari kerjasama yang baik antara pimpinan dan bawahan. Tujuan penelitian ini adalah menganalisis gaya komunikasi kepemimpinan dan menganalisis peran komunikasi pimpinan kepada bawahan dalam meningkatkan pelayanan prima pada Badan Pelayanan Perizinan Terpadu Kota Banjarbaru. Penelitian ini menggunakan pendekatan kualitatif deskriptif. Data diperoleh dari wawancara mendalam dengan informan. Hasil wawancara dianalisis secara deskriptif dan secara kualitatif melalui tahapan reduksi data, sajian data, dan kesimpulan. Hasil penelitian menunjukkan bahwa Gaya komunikasi kepemimpinan menunjukkan tipe yang partisipatif. Peran komunikasi kepemimpinan mendukung bawahan dalam melaksanakan tugasnya. Proposisi yang dihasilkan dari hasil pembahasan adalah 1.Interaksi yang dilakukan pimpinan kepada bawahan dengan menggunakan gaya komunikasi pimpinan partisipatif dalam menyampaikan informasi maupun pesan mampu meningkatkan motivasi bawahan dalam pelayanan publik. 2.Gaya komunikasi pimpinan yang diterapkan kepada bawahan mendapat dukungan penuh didalam organisasi pelayanan publik sehingga tujuan organisasi dapat dicapai. 3.Kemampuan pimpinan dalam mengemban tugas memimpin dan menjalankan organisasi berpengaruh terhadap keberhasilan pelayanan publik.
\end{abstract}

Kata kunci : peran komunikasi pimpinan, pelayanan publik

\begin{abstract}
In most aspects, public service is still considered to be unsatisfactory, except in the Integrated Licensing Service Agency (BPPT), a Government Agency that has made a difference from most public organizations. Several awards that have been received by BPPT are the indicator that shows the result of a good cooperation between the leader and the subordinates. The aim of this study is to analyze the leadership communication style and to analyze the role of communication from the leader to the subordinates in improving the service excellence in the Integrated Licensing Service Agency of Banjarbaru City. This study uses descriptive qualitative approach. The data is obtained through personal interviews with the informant. The interview result is analyzed using descriptive and qualitative approach through the phases of data reduction, data presentation, and conclusion. The result of this study shows that the leadership communication style has shown the type of participation. The role of leadership communication supports the subordinates in carrying out their tasks. The proposition resulted from the discussion are as follows; 1 . The interaction that have been done by the leader to the subordinates, using the participatory leadership communication style in conveying the information or message, can improve the spirit and motivation of the subordinates in carrying out the public service; 2. The leadership communication style that has been implemented to the subordinates is fully supported in public service organization, so that the organizational goal can be achieved; 3 . The leadership and organizing ability from the leader affect the success rate of public service.
\end{abstract}

Key words: role of leadership communication, public service

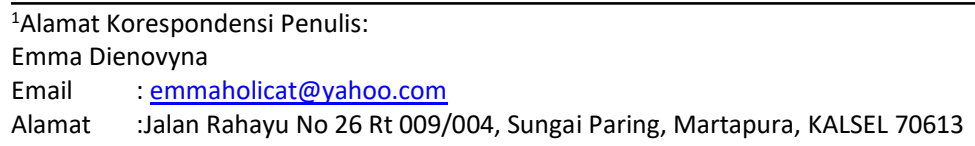




\section{PENDAHULUAN}

Komunikasi merupakan salah satu faktor yang penting bagi manusia dalam kehidupan sehari-hari, baik secara individu, kelompok, maupun dalam organisasi. Pentingnya sebuah komunikasi mendorong setiap organisasi untuk dapat menutupi jurang yang terbentang antara pihak pemerintah dengan masyarakat sebagai publiknya guna membina hubungan yang lebih baik, khususnya di bidang pelayanan publik.

Komunikasi adalah pertukaran informasi dan penyampaian makna yang merupakan hal utama dari suatu sistem sosial atau organisasi.Dengan kata lain, orang mempelajari komunikasi organisasi organisasi untuk menjadi pimpinan yang lebih baik[1]. Hubungan antara komunikasi dan organisasi terletak pada peninjauannya yang terfokus pada manusia yang terlibat dalam mencapai tujuan organisasi [2]. Griffin dalam A First Look at Communication Theory, membahas komunikasi organisasi mengikuti teori management klasik, yang menempatkan suatu bayaran pada daya produksi, presisi, dan efisiensi[3].

Tidak ada organisasi tanpa komunikasi, karena komunikasi merupakan bagian integral dari organisasi. Komunikasi ibarat sistem yang menghubungkan antar orang, antar bagian dalam organisasi, atau sebagai aliran yang mampu membangkitkan kinerja orang-orang yang terlibat di dalam organisasi tersebut. Komunikasi yang dilakukan harusnya didukung kepemimpinan yang efektif dari pimpinan untuk mengerahkan, menggerakkan, mengarahkan bawahan untuk mencapai tujuan. Pimpinan harus dapat menggunakan gaya komunikasi kepemimpinan dengan baik untuk memotivasi bawahan dalam meningkatkan kualitas pelayanan publik.

Pelayanan publik dilakukan oleh instansi pemerintah dewasa ini masih belum dapat memenuhi kualitas pelayanan yang diharapkan masyarakat, hal ini terjadi karena dibeberapa aspek masih banyak terdapat kendala yang langsung maupun tidak langsung berdampak pada pencapaian kualitas pelayanan itu sendiri. Keluhan maupun pengaduan masyarakat baik langsung maupun melalui media massa menjadi tolak ukur baiknya kualitas layanan publik yang diberikan instansi masyarakat.

Badan Pelayanan Perizinan Terpadu adalah organisasi pemerintahan yang bergerak pada bidang pelayanan perizinan di banjarbaru yang berusaha merubah citra buruk akan pelayanan publik di mata masyarakat dengan Visi "Terdepan dalam Pelayanan
Perizinan Terpadu Satu Pintu yang Prima dan Bebas KKN", dan Misi "Mewujudkan Pelayanan Terpadu Satu Pintu Yang Prima". Badan Pelayanan Perizinan Terpadu Kota Banjarbaru Provinsi Kalimantan Selatan tentunya berusaha memberikan jaminan kepastian dan kemudahan pelayanan perizinan yang diberikan kepada masyarakat.

Berdasarkan pengamatan awal diperoleh fenomena pada Badan Pelayanan Periznan Terpadu Kota Banjarbaru terlihat bahwa ada beberapa pegawai yang kadang terlambat datang kekantor tanpa alasan yang jelas. Ada yang keluar kantor setelah apel dengan alasan sarapan pagi sehingga ada kemungkinan memperlambat proses pelayanan. Untuk merubah citra buruk akan pelayanan publik di mata masyarakat, Badan Pelayanan Periznan Terpadu Kota Banjarbaru memiliki Visi "Terdepan dalam Pelayanan Perizinan Terpadu Satu Pintu yang Prima dan Bebas KKN", dan Misi "Mewujudkan Pelayanan Terpadu Satu Pintu Yang Prima".

Pelayanan publik yang dilakukan oleh instansi pemerintah dewasa ini masih belum dapat memenuhi kualitas pelayanan yang diharapkan masyarakat, hal ini terjadi karena di beberapa aspek masih banyak terdapat kendala yang langsung maupun tidak langsung berdampak pada pencapaian kualitas pelayanan itu sendiri. Keluhan maupun pengaduan masyarakat baik langsung maupun melalui media massa menjadi tolak ukur kurang baiknya kualitas layanan publik yang diberikan instansi pemerintah.

Salah satu bentuk upaya meningkatkan kualitas pelayanan publik adalah dengan menyusun Indeks Kepuasan Masyarakat (IKM) yang dapat dijadikan sebagai tolak ukur untuk menilai tingkat kualitas pelayanan yang diberikan. Hal ini sesuai dengan apa yang diamanatkan dalam Undang-undang RI Nomor 25 Tahun 2000 tentang Program Pembangunan Nasional (Propenas) yang menyebutkan bahwa salah satu upaya untuk meningkatkan kualitas pelayanan publik adalah dengan menyusun Indeks Kepuasan Masyarakat (IKM).

Penyusunan Indeks Prestasi Kepuasan Masyarakat (IKM) menjadi acuan untuk penilaian terhadap unsur pelayanan yang diberikan. Penyusunan Indeks Kepuasan Masyarakat (IKM) juga dapat dijadikan sebagai pendorong bagi setiap unit penyelenggaraan pelayanan publik untuk meningkatkan kualitas pelayanan yang diberikan.

Hal yang mendasari penyusunan Indeks Kepuasan Masyarakat (IKM) adalah Keputusan Menteri Pendayagunaan Aparatur Negara Nomor KEP/25/M.PAN/2/2004 tanggal 24 Februari 2004 
tentang Pedoman Umum Penyusunan Indeks Kepuasan Masyarakat Unit Pelayanan Instansi Pemerintah.

Pada tahun 2006, ketika penyelenggaraan Perizinan Terpadu masih menjadi kantor yaitu Kantor Pelayanan Perizinan Terpadu (KP2T) telah dilakukan Survey Indeks Kepuasan Masyarakat terhadap kinerja KP2T sebagai lembaga pelayanan perizinan. Dari survey yang dilakukan terhadap 150 orang responden dengan 10 (sepuluh) unsur pelayanan yang dinilai dapat diperoleh hasil/ukuran kinerja dengan nilai 66,65 maka mutu pelayanan adalahBaik.

Ada beberapa unsur pelayanan yang mempunyai nilai terendah yaitu: Kemampuan Petugas untuk mengatasi masalah, ini diperlukan upaya peningkatan kemampuan, pengetahuan dan keterampilan aparatur melalui keikutsertaan pada program / kegiatan pelatihan atau bimbingan teknis pelayanan publik.

Tahun 2007 dilaksanakan lagi penyusunan Indeks Kepuasan Masyarakat dari 150 orang responden dan 14 (empat belas) unsur pelayanan yang dinilai didapat hasil pengukuran adalah 75,73 maka mutu pelayanan adalahBaik. Untuk nilai tertinggi adalah Kedisiplinan Petugas Pelayanan, sedangkan nilai terendah adalah terkait dengan Kemampuan Petugas Pelayanan.

Pada Tahun 2008, Kantor Pelayanan Perijinan Terpadu (KP2T) meningkatkan status kelembagaannya menjadi Badan Penanaman Modal dan Perizinan, yaitu Integrasi antara Bidang Penanaman Modal dengan Bidang Perizinan. Pada tahun ini juga dilaksanakan penyusunan Indeks Kepuasan Masyarakat dengan unsur penilaian sebanyak 14 unsur. Dari hasil pengukuran didapat nilai IKM unit pelayanan adalah 80,24 maka Mutu Pelayanan adalahBaik.

Dari hasil pengukuran nilai terendah adalah Kenyamanan Ruang Pelayanan, oleh sebab itu telah diupayakan melakukan penataan ruang pelayanan sedemikian rupa agar suasana dan kondisi ruang pelayanan sejuk, indah dan nyaman.

Pada tahun 2009 Badan Pelayanan Perizinan Terpadu Kota Banjarbaru terus melaksanakan penyusunan IKM dengan unsur penilaian sebanyak 14 (empat belas) unsur. Dari hasil pengukuran didapat nilai IKM $=81,01$ maka mutu pelayanan adalahBaik. Untuk nilai tertinggi adalah Kesopanan dan Keramahan petugas, sedangkan nilai terendah adalah Kenyamanan Lingkungan.

Pada tahun 2010 Badan Pelayanan Perizinan Terpadu Kota Banjarbaru masih melaksanakan penyusunan IKM dengan unsur penilaian sebanyak 14 (empat belas) unsur. Dari hasil pengukuran didapat nilai IKM $=81,18$ maka mutu pelayanan adalahBaik. Untuk nilai tertinggi adalah Kesopanan dan Keramahan Petugas sama dengan penilaian tahun 2009, sedangkan nilai terendah adalah Kepastian Jadual Unit Pelayanan.

Pada tahun 2010 Badan Pelayanan Perizinan Terpadu Kota Banjarbaru melakukan penyusunan IKM dengan unsur penilaian sebanyak 14 (empat belas) unsur. Dari hasil pengukuran didapat nilai IKM = 81,24 maka mutu pelayanan sama dengan Baik. Untuk nilai tertinggi adalah Kesopanan dan Keramahan Petugas sama dengan penilaian tahuntahun lalu, sedangkan nilai terendah adalah Kenyamanan Lingkungan.

Dari hasil penilaian IKM tersebut menjadi tolak ukur bagi Badan Pelayanan Perizinan Terpadu Kota Banjarbaru untuk berusaha mendorong dan memperbaiki kualitas pelayanan perzinannya. Untuk mencapai keberhasilan dalam pelayanan publik tersebut, dalam penelitian ini meneliti kemampuan pimpinan berkomunikasi menyampaikan pendapat dan ide-idenya yang bisa dipahami dan dapat dilaksanakan oleh para bawahannya. Komunikasi ini juga menjadi sarana untuk mengubah tingkah laku, dengan jalan mempengaruhi dan meyakinkan para bawahan agar pelayanan publik yang prima dapat tercapai.

Semakin baiknya pelayanan publik yang dilakukan tentunya juga akan memberikan dampak antara lain menguntungkan masyarakat, para investor dan pemerintah Kota Banjarbaru sendiri, yang memperoleh pemasukan dari retribusi dan pajak pendirian usaha atau pajak pendirian bangunan. Beberapa penghargaan yang diterima Badan Pelayanan Perizinan Terpadu Kota Banjarbaru tentunya tidak lepas dari peran pimpinan. Untuk mengetahui perkembangan dan hasil dari peningkatan kinerja para pegawai, berikut adalah prestasi yang dicapai oleh Badan Pelayanan Perizinan Terpadu Kota Banjarbaru.

\begin{tabular}{|l|l|l|}
\hline 1 & 2004 & $\begin{array}{l}\text { Unit kerja TERBAIK - II Penerangan } \\
\text { BUDAYA KERJA di lingkungan } \\
\text { pemerintah Kota Banjarbaru }\end{array}$ \\
\hline 2 & 2004 & $\begin{array}{l}\text { Unit kerja TERBAIK - I penerapan } \\
\text { BUDAYA BERSIH di lingkungan Kota } \\
\text { Banjarbaru }\end{array}$ \\
\hline 3 & 2005 & $\begin{array}{l}\text { Unit kerja TERBAIK - III LOMBA } \\
\text { KEBERSIHAN di lingkungan } \\
\text { pemerintah Kota Banjarbaru }\end{array}$ \\
\hline
\end{tabular}




\begin{tabular}{|c|c|c|}
\hline 4 & 2006 & $\begin{array}{l}\text { Unit kerja TERBAIK - I Pelaksana } \\
\text { Pekan Disiplin Mandiri di lingkungan } \\
\text { pemerintah Kota Banjarbaru }\end{array}$ \\
\hline 5 & 2006 & $\begin{array}{ll}\text { Unit kerja } & \text { TERBAIK - I Pelaksana } \\
\text { Gerakan Disiplin Mandiri di } \\
\text { lingkungan pemerintah Kota } \\
\text { Banjarbaru }\end{array}$ \\
\hline 6 & 2006 & $\begin{array}{l}\text { Stand Pameran TERBAIK }- \text { I pada } \\
\text { DECEMBER FAIR 2006 } 1 \quad-7 \\
\text { Desember } \quad 2006 \quad r \text { yang } \\
\text { diselenggarakan oleh Dekranasda } \\
\text { Kota Banjarbaru bekerjasama } \\
\text { dengan Radar Banjar di Lapangan } \\
\text { Dr. Murjani Banjarbaru }\end{array}$ \\
\hline 7 & 2007 & $\begin{array}{l}\text { Unit Pelayanan Publik TERBAIK - II } \\
\text { "Citra Pelayanan Prima Tahun } \\
\text { 2007" se Kalimantan Selatan }\end{array}$ \\
\hline 8 & 2007 & $\begin{array}{l}\text { TERBAIK - III Penyelenggaraan } \\
\text { Terpadu Satu Pintu Tingkat Nasional }\end{array}$ \\
\hline 9 & 2007 & $\begin{array}{l}\text { Unit kerja TERBAIK - I Pelaksanaan } \\
\text { Gerakan Disiplin Mandiri di } \\
\text { lingkungan pemerintah Kota } \\
\text { Banjarbaru }\end{array}$ \\
\hline 10 & 2011 & $\begin{array}{l}\text { TERBAIK - I "Citra Pelayanan Prima" } \\
\text { Unit Pelayanan Publik yang berhasil } \\
\text { meningkatkan kualitas pelayanan } \\
\text { publik di Kota Banjarbaru tahun } \\
2011\end{array}$ \\
\hline
\end{tabular}

Tabel 1 Prestasi Badan Pelayanan Perizinan

Terpadu Kota Banjarbaru

Sumber : arsip Badan Pelayanan Perizinan Terpadu Kota Banjarbaru

Dalam beberapa wawancara yang sebelumnnya dilakukan kepada pengguna pelayanan pada Badan Pelayanan Perizinan Terpadu Kota Banjarbaru diakui bahwa masyarakat merasa cukup puas dengan pelayanan yang diberikan. Koordinasi yang baik yang dilakukan pimpinan untuk mendorong bawahan menunjukkan kinerja yang baik dalam bidang pelayanan menjadi pembeda Badan Pelayanan Perizinan Terpadu Kota Banjarbaru dengan badan pelayanan ditempat lain. Seorang pimpinan harusnya mampu menggunakan kemampuan berkomunikasi dengan bawahan agar kegiatan pelayanan kepada masyarakat tidak terganggu. Karena penting bagi sebuah pelayanan publik yang dilakukan oleh pemerintah untuk membina hubungan baik yang dinamis dan harmonis kepada para masyarakat serta mengoptimalkan komunikasi yang efektif.
Menurut Kerlinger dan Padhazur [4], faktor kepemimpinan mempunyai peran yang sangat penting dalam meningkatkan kinerja pegawai karena kepemimpinan yang efektif memberikan pengarahan terhadap usaha-usaha semua pekerja dalam mencapai tujuan-tujuan organisasi. Dlibutuhkan Pimpinan yang memiliki gaya komunikasi kepemimpinan yang efektif untuk dapat meningkatkan kinerja semua pegawai dalam mencapai tujuan organisasi sebagai instansi pelayanan publik.

Pelayanan perizinan Kota Banjarbaru diawali dengan mendirikan Kantor Pelayanan Perizinan Terpadu (KP2T) yang kemudian berubah menjadi Badan Pelayanan Perizinan Terpadu (BP2T) bukan semata-mata respon terhadap Peraturan Pemerintah No. 27 Tahun 2009 mengenai Pelayanan Satu Pintu di Bidang Pelayanan Modal dan Permendagri No.24 Tahun 2006 mengenai Pedoman Penyelenggaran Pelayanan Terpadu Satu Pintu, tetapi lebih dikarenakan adanya keinginan untuk menciptakan pelayanan perizinan yang sederhana,cepat, dan transparan.

Pelayanan publik pada Badan Pelayanan Perizinan Terpadu Kota Banjarbaru tidak lepas dari adanya kontrol seorang pimpinan. Gaya komunikasi kepemimpinan memiliki peran penting dalam meningkatan kualitas kinerja pelayanan publik.Dalam mencapai tujuan organisasi, pimpinan tidak diperkenankan untuk menggunakan gaya komunikasi kepemimpinan yang memaksa.

Gaya komunikasi kepemimpinan merupakan norma yang digunakan sewaktu mencoba mempengaruhi perilaku orang lain. Oleh karena itu perilaku dasar seorang pimpinan merupakan tanggapan dari bawahannya. Terkait dengan kepemimpinan maka komunikasi yang baik sangatlah penting dimiliki oleh pimpinan. Dengan komunikasi yang baik, pimpinan memberikan kenyamanan, sehingga bawahannya tidak kaku dalam menyampaikan informasi kepadanya.

Dalam mempengaruhi bawahan untuk mencapai suatu tujuan tersebut, pimpinan tentunya memiliki gaya komunikasi kepemimpinan yang diterapkan berdasarkan kepada norma dan institusi nilai tertentu sesuai dengan kondisi didalam organisasi.Prestasi yang diraih pada Badan Pelayanan Perizinan Terpadu Kota Banjarbaru tidak terlepas dari adanya pengaruh kepemimpinan yang diterapkan kepada seluruh bawahan. Pimpinan tentunya memiliki peran penting dan bawahan juga menjadi bagian dalam tercapainya pelayanan prima yang diharapkan. 
Berdasarkan uraian fenomena dan permasalahan yang tampak pada Badan Pelayanan Perizinan Terpadu Kota Banjarbaru dan mengangkatnya ke dalam penelitian dengan judul "Peran Komunikasi Pimpinan Kepada Bawahan Dalam Meningkatkan Pelayanan Prima".

Rumusan masalah dalam penelitian ini adalah Bagaimanakah Gaya Komunikasi Kepemimpinan Pada Badan Pelayanan Perizinan Terpadu Kota Banjarbaru Provinsi Kalimantan Selatan? Dan Bagaimanakah Peran Komunikasi Pimpinan Kepada Bawahan Dalam Meningkatkan Pelayanan Prima Pada Badan Pelayanan Perizinan Terpadu Kota Banjarbaru Provinsi Kalimantan Selatan?

Tujuan penelitian ini adalah Menganalisis Gaya Komunikasi Kepemimpinan Pada Badan Pelayanan Perizinan Terpadu Kota Banjarbaru Provinsi Kalimantan Selatan dan Menganalisis Peran Komunikasi Pimpinan Kepada Bawahan Dalam Meningkatkan Pelayanan Prima Pada Badan Pelayanan Perizinan Terpadu Kota Banjarbaru Provinsi Kalimantan Selatan.

\section{METODE PENELITIAN}

Dalam penelitian mengenai Peran Komunikasi Pimpinan Kepada Bawahan Dalam Meningkatkan Pelayanan Prima pada Badan Pelayanan Perizinan Terpadu Kota Banjarbaru, digunakan metode kualitatif dengan pendekatan deskriptif. Penelitian deskriptif kualitatif ini hanya menggambarkan permasalahan yang ada dalam kaitannya dengan gaya komunikasi kepemimpinan dan peran komunikasi pimpinan kepada bawahan yang diterapkan pada Badan Pelayanan Perizinan Terpadu Kota Banjarbaru. Penelitian dilakukan pada Badan Pelayanan Perizinan terpadu yang beralamat di Jl. Wijaya Kusuma No. 3 Telp. (0511) 4781711 Fax. (0511) 4781886 Banjarbaru 70711 provinsi Kalimantan Selatan.

Untuk memperoleh data yang valid dan relevan dalam penelitian ini digunakan metode pengumpulan data sebagai berikut sebagai berikut :

1. Wawancara Mendalam (Depth Interview) Wawancara yaitu mengadakan komunikasi langsung dengan responden melalui tatap muka guna menghimpun data yang dibutuhkan dalam penelitian. Oleh karena itu dibuat beberapa pedoman yang akan digunakan untuk mewawancarai informan. Informan dalam penelitian ini diambil melalui sampel yang ditetapkan secara purposive. Metode purposive sampling yaitu penentuan sampel untuk tujuan atau pertimbangan tertentu[5]. Wawancara dilakukan berdasarkan daftar pertanyaan yang sudah disusun. Penggunaan teknik wawancara terbuka (overt) dipilih agar responden mengetahui bahwa mereka sedang diwawancarai dan mengetahui pula maksud wawancara tersebut. Informan dipilih karena dianggap terlibat langsung dalam kepemimpinan dan pelaksanaan publik pada Badan Pelayanan Perizinan Terpadu Kota Banjarbaru. Sehingga yang dipilih adalah yang menduduki kursi pimpinan pada Badan Pelayanan Perizinan Terpadu Kota Banjarbaru. Terdiri dari 5 orang yang menduduki jabatan dari Kepala Badan Pelayanan Perizinan Terpadu Kota Banjarbaru, Sekretaris Badan Pelayanan Perizinan Terpadu, Kabid Pelayanan Perizinan Paralel, Kabid Pelayanan Non Perizinan dan Kabid Pelayanan Perizinan.

2. Observasi (pengamatan)

Dalam penelitian ini digunakan pengamatan tanpa berperan serta tertutup yakni mengadakan pengamatan tanpa mengganggu aktivitas-aktivitas yang ada pada Badan Pelayanan Perizinan Terpadu Kota Banjarbaru, dimana subjek tidak mengetahui adanya pengamatan yang sedang dilakukan sehingga diharapkan data-data yang diperoleh sesuai dengan kondisi real di lapangan. Seperti melakukan observasi[5] untuk melihat suasana kerja serta komunikasi yang terjalin antara pimpinan dengan bawahan dan sebaliknya pada Badan Pelayanan Perizinan Terpadu Kota Banjarbaru. Observasi awal dilakukan sebelum penelitian, dan dilanjutkan kembali pada saat penyusunan tesis. Observasi mencakup wawancara dan dokumentasi.

3. Studi Pustaka

Sumber data yang digunakan oleh peneliti dimulai dari buku - buku, dokumen resmi, artikel serta jurnal penelitian dimana informasi yang diperoleh bertujuan untuk mendukung penelitian tentang pada Badan Pelayanan Perizinan Terpadu Kota Banjarbaru. Hal ini dilakukan untuk memperoleh data-data empiris untuk mengetahui seberapa jauh peran komunikasi pimpinan terhadap bawahan dalam meningkatkan pelayanan prima pada Badan Pelayanan Perizinan Terpadu Kota Banjarbaru. Setelah data yang diperlukan diperoleh, baik dari wawancara, pengamatan, maupun studi dokumen tahap selanjutnya dengan menganalisis data adalah data yang diperoleh 
untuk direduksi, kemudian data disajikan dan seterusnya ditarik kesimpulan.

\section{HASIL DAN PEMBAHASAN}

1. Analisis Gaya Komunikasi Kepemimpinan Pada Badan Pelayanan Perizinan Terpadu

Komunikasi dengan kepemimpinan sangat erat hubungannya. Seorang pemimpin harus memiliki wawasan yang luas, jujur, bertanggung jawab, berani dalam mengambil keputusan, dan juga mempunyai keahlian berkomunikasi yang sangat baik. Karena komunikasi dapat menentukan berhasil atau tidaknya pimpinan dalam menjalankan tugasnya. Setiap pimpinan pasti memiliki bawahannya dimana bawahannya tersebut dapat mengeluarkan gagasan/ide yang akan dipaparkan yang dapat dipertimbankan.

Kepemimpinan yang berhasil mempengaruhi orang lain sangat ditentukan oleh keterampilan dan kemampuan menjalankan fungi komunikasi secara baik karenanya komunikasi yang baik dan menjadi efektif akan ditentukan pula oleh kepercayaan dan keyakinan pimpinan dalam memimpin untuk mempengaruhi bawahan. Keyakinan dan kepercayaan hanya dapat terbentuk apabila pimpinan menyadari suatu lingkungan yang harmonis antara pimpinan dengan para bawahannya yang dapat benar-benar berkomunikasi dengan baik. Likert membagi gaya manajerial tersebut terdiri dari gaya otoritatif dan eksploitif, gaya otoritatif dan benevolent, gaya konsultatif dan gaya partisipatif [6].

Penelitian ini ditekankan kepada komunikasi yang dilakukan dalam internal organisasi. Komunikasi internal organisasi adalah proses penyampaian pesan yang dikirim dan diterima di dalam suatu organisasi baik yang formal maupun informal [7]. Seperti komunikasi antara pimpinan dengan bawahan, antar sesama bawahan, dan sebagainya. Komunikasi ini hanya berlangsung di dalam lingkungan itu sendiri. komunikasi ke atas[8] adalah pesan yang mengalir dari bawahan kepada atasan atau dari tingkat yang lebih rendah kepada tingkat yang lebih tinggi. Tujuan dari komunikasi ini adalah pemberian balikan, memberikan saran dan mengajukan pertanyaan. Komunikasi ke atas mempunyai beberapa alasan mengapa komunikasi keatas penting [9].

Pada saat wawancara dan observasi, ditemukan beberapa hal yang berkaitan mengenai gaya komunikasi kepemimpinan yang diterapkan pada Badan Pelayanan Perizinan Terpadu Kota Banjarbaru. Mengingat bahwa Badan Pelayanan
Perizinan Terpadu Kota Banjarbaru merupakan salah satu sektor pelayanan publik yang bergerak dibidang perizinan telah menunjukkan kemajuan dalam bidang pelayanan kepada masyarakat.

Keberadaan Badan Pelayanan Perizinan Terpadu (BP2T) Kota Banjarbaru berawal dari kebijakan pemerintah untuk penyederhanaan penyelenggaraan Pelayanan Terpadu Satu Pintu dan dalam rangka mendorong perubahan ekonomi melalui peningkatan investasi di daerah, maka Pemerintah Kota membentuk Kantor Pelayanan Periznan Terpadu (BP2T) Kota Banjarbaru dengan berdasarkan Perda Kota Banjarbaru No. 19 Tahun 2003.

Sejak awal dibentuknya, pimpinan mempunyai peran yang sangat penting dalam kemajuan organisasi. Beberapa bawahan mengatakan, pimpinan yang sebelumnya sudah menanamkan kondisi kinerja yang baik kepada bawahannya. Komunikasi yang terjadi antara pimpinan dan bawahan berjalan dengan baik. Pimpinan pada Badan Pelayanan Perizinan Terpadu Kota Banjarbaru mampu menempatkan posisinya sebagai seorang pimpinan yang dapat menggerakkan bawahannya dengan cukup baik. Dalam hal ini kepala badan sebagai pimpinan atas pada Badan Pelayanan Perizinan Terpadu Kota Banjarbaru bekerja dengan penuh rasa tanggung jawab, baik tanggung jawab akan pekerjaannya maupun tanggung jawab terhadap bawahannya.

Pimpinan sebelumnya mengajarkan dan memberikan bimbingan kepada bawahan tentang bekerja yang baik dan menunjukkan perilaku yang patut dicontoh. Seperti hasil observasi pada Badan Pelayanan Perizinan Terpadu Kota Banjarbaru saat beberapa pimpinan berada di tempat, dapat dilihat adanya kedekatan emosional antara pimpinan. Dilihat dari komunikasi nonverbal yang para pimpinan lakukan. Seperti berjabat tangan dengan penuh semangat yang diiringi dengan senyum dari masing-masing pimpinan. Dengan kedekatan antar pimpinan menggunakan komunikasi kepemimpinan yang bersifat kekeluargaan dapat berjalan dengan baik.

Antar pimpinan dan bawahan bekerja bersama, dari bertukar pikiran, bertukar ilmu, dan bertukar informasi satu sama lain, karena mereka berasal dari berbagai macam latar belakang, jadi masih wajar bila terkadang ada perbedaan dan ketidak nyamanan satu sama lain. Dari kejadian-kejadian itu mereka bisa lebih memberikan pemahaman atas proses komunikasi organisasi yang efektif sekalipun dalam bersikap dan menghargai orang lain untuk konteks 
organisasi, dengan visi "Terdepan dalam pelayanan perizinan terpadu satu pintu yang prima dan bebas KKN" dan misi "Mewujudkan pelayanan terpadu satu pintu yang prima ".

Dalam suasana formal, pimpinan banyak bersikap tegas, terbuka dalam adanya informasi, serta pengambilan keputusan dari persetujuan bersama. Sedangkan ecara informal bersikap sangat santai, terbuka pada bawahannya, terdapat rasa kekawanan yang dihasilkan sehingga tidak ada keraguan, rasa malu dalam berkomunikasi serta menjadi contoh yang baik, dalam bekerja, bersikap dan lain-lain.

Dalam menghadapi permasalahan maupun hambatan yang dihadapi yang hubungannya dengan pekerjaan, pimpinan yang dalam hal ini kassubbag maupun kabbid masing-masing bagian selalu melakukan koordinasi. Apabila ada bawahan yang mengalami musibah, atau masalah keluarga. Pimpinan akan memberikan toleransi dan dukungan. Saran mungkin akan diperlukan, apabila diperlukan. Sebagai contoh, apabila bawahan mengalami kendala atau penurunan kinerja, maka kassubbid atau kasubbag akan melakukan pemanggilan dan sharing masalah apa yang sedang dihadapi.

Menurut wawancara dengan beberapa pimpinan kabid, dalam hal kepemimpinanya terkait aturan tentang hukuman yang dilakukan oleh bawahanya apabila melakukan pelanggaran sebisanya diberikan hukuman sesuai peraturan. Namun sebelumnya diberikan bimbingan dan nasihat secara santai dan tidak dalam kondisi marah, bahkan memberikan sebuah pesan motivasimotivasi.

Diakui oleh para pegawai pada Badan Pelayanan Perizinan Terpadu Kota Banjarbaru, hubungan interaksi dan komunikasi yang terjalin antara pimpinan dan bawahan berlangsung baik. Dengan dukungan dari kepala bidang masing-masing yang selalu mengarahkan dan berusaha mengkomunikasikan permasalahan dengan baik. Hal ini juga didukung kepemimpinan terdahulu, sehingga kinerja didalam kantor sudah memiliki pola kerja yang teratur dan tertata.

Dari hasil temuan dapat dilihat gaya komunikasi kepemimpinan pada masing-masing bagian terjadi pada Badan Pelayanan Perizinan Terpadu Kota Banjarbaru. Dalam komunikasi downward, yang mana menjelaskan tentang penerapan proses komunikasi dari atasan ke bawahannya. Pola komunikasi downward yang diterapkan adalah merupakan komunikasi umpan balik yang bernuansakan kekeluargaan.
Komunikasi yang diterapkan dalam gaya komunikasi pimpinan secara lisan dari pimpinan ke bawahan lebih sering digunakan, dengan demikian penyampaian informasi yang disampaikan oleh pimpinan dapat diterima langsung oleh bawahan sehingga bisa meminimalisir miscommonnication dan dapat meningkatkan mutu pelayanan itu sendiri. Jadi, disini dapat dilihat bahwa pada setiap diri pimpinan dan bawahan pada masing-masing bagian ataupun bidang berusaha memahami satu sama lain untuk dapat memperlancar komunikasi.

Gaya komunikasi kepemimpinan pada Badan Pelayanan Perizinan Terpadu dengan menggunakan gaya partisipatif dianggap sebagai gaya yang nyaman dipakai dan diterapkan sehari-hari. Satu hal penting dari gaya partisipatif adalah, walaupun keputusan diambil bersama-sama antara atasan dan bawahan, bukan berarti pemimpin meninggalkan tanggung jawab terbesar dalam pengambilan keputusan [10]. Komunikasi dua arah dan pengambilan keputusan turut melibatkan bawahan pada saat rapat untuk menetapkan kebijakan, dimana selalu melibatkan perwakilan tiap seksi untuk menghadiri rapat dan menanyakan kepada perwakilan tiap seksi mengenai masalah-masalah yang terjadi, dan didiskusikan bersama untuk mendapatkan solusi yang terbaik.

Gaya partisipatif dengan memberikan kepercayaan kepada bawahan melakukan pekerjaan tapi tetap menghargai dan tidak semena-mena dalam memberikan perintah adalah perilaku komunikasi yang baik antara pimpinan dan bawahan. Komunikasi tetap terjalin keatas maupun kebawah, TUPOKSI yang diberikan jelas, bawahan boleh memberikan saran dan bisa menanyakan apabila ada pekerjaan yang tidak jelas.

\section{Analisis Peran Komunikasi Pimpinan Terhadap Bawahannya Dalam Meningkatkan Pelayanan Prima Pada Badan Pelayanan Perizinan Terpadu Kota Banjarbaru.}

Dalam peran pimpinan kepada bawahan pada Badan Pelayanan Perizinan Terpadu kota Banjarbaru, seorang pimpinan melakukan proses komunikasi dengan bawahan untuk memberikan informasi dan mendapatkan informasi kembali dari bawahan tersebut, begitu pula dengan pimpinan. Hal ini akan menimbulkan interaksi komunikasi yang berkesinambungan dan terus berlanjut hingga terciptanya kesepemahaman di dalam proses komunikasi. Informasi yang di dapatkan pun akan menguntungkan kedua belah pihak dan menciptakan sebuah kepuasan publik dan motivasi dalam bekerja bagi bawahan dalam meningkatkan pelayanan 
prima.Teori peran (Role Theory) merupakan implikasi selanjutnya dari interaksi simbolik [11]. dimana, salah satu aktivitas paling penting yang dilakukan manusia setelah proses pemikiran (thought) adalah pengambilan peran (role taking). Teori peran menekankan pada kemampuan individu secara simbolik dalam menempatkan diri diantara individu lainnya ditengah interaksi sosial masyarakat.

Peran pimpinan sebagai komunikator menyatakan wewenang formal seorang manajer menyebabkan timbulnya tiga peranan[12]:

1. Peran interpersonal (interpersonal role)

Dalam hubungan interpersonal terdapat tiga peran pimpinan yang muncul secara langsung dari otoritas formal yang dimiliki pimpinan dan mencakup hubungan interpersonal dasar. Dari hasil observasi, wawancara dan data dari beberapa sumber yang didapat menunjukkan bahwa dalam menjalankan peran interpersonal yang terdiri dari peran tokoh, peran pemimpin dan peran sebagai Penghubung mampu dilakukan dengan baik oleh para pimpinan pada Badan Pelayanan Perizinan Terpadu Kota Banjarbaru.

Peran tokoh yang dilakukan pimpinan melakukan pertemuan-pertemuan dengan pimpinan tertinggi, maupun pimpinan pada badan atau bagian yang lain pada saat rapat. Pimpinan mampu menempatkan diri sebagai salah satu pimpinan yang baik dan disegani. Seperti contoh rapat di kantor DPR yang memerlukan kehadiran kepala badan. Maka kepala badan akan berusaha hadir dan kadang membawa bawahan yang diperkirakan mengerti akan permasalahan yang mungkin dihadapi saat rapat. Pimpinan juga kadang mengajak serta beberapa bawahan melakukan rapat diluar kantor dengan walikota atau dinas lain salah satunya bertujuan untuk mengajarkan kepada bawahan tentang pengalaman berdiskusi. Peran pemimpin seperti dalam memimpin rapat, menjaga koordinasinyang baik dengan bawahan. Rapat dilakukan sebulan sekali. Maupun dalam memimpin apel pagi setiap hari. Peran pimpinan sebagai penghubung salah satunya tercapainya bekerjasama dengan sektor swasta, dengan menggandeng salah satu ATPM sepeda motor nasional, yaitu Suzuki. .

Walaupun dari penilaian beberapa bawahan, dalam hal ini para pegawai di Badan Pelayanan Perizinan Terpadu Kota Banjarbaru tentang peran pimpinan dalam memberikan motivasi kepada para pegawainya, diperoleh gambaran bahwasanya peran pimpinan dalam memberikan motivasi positif kepada para pegawainya masih dianggap kurang. Keengganan dari bawahan sendiri untuk menyampaikan maksudnya kepada pimpinan. Pimpinan memberikan kebebasan kepada bawahan untuk menyampaikan saran pada saat rapat atau pada saat komunikasi terbuka. Tetapi kadang bawahan melihat situasi dan kondisi pimpinan terlebih dahulu, apakah pimpinan tidak sedang sakit atau apakah pimpinan tidak sedang sibuk.

Sehingga bawahan lebih berharap akan pengertian langsung dari pimpinan. Kurangnya komunikasi yang baik terhadap pegawainya mengakibatkan terjadinya miscommunication antara pimpinan dengan bawahannya. Komunikasi yang dianggap kurang disini menurut bawahan juga dinilai untuk pimpinan yang kadang kaku dalam memberikan motivasi. Sebagai contoh, dalam pemberian tugas dari pimpinan kepada bawahan cuma sekedar pemberitahuan apa tugas yang harus dilakukan saja. Sedangkan dukungan agar semangat menyelesaikan tugas masih jarang dilakukan. Pemberian motivasi saat apel pagi dan rapat dianggap satu-satunya cara yang dilakukan oleh pimpinan.

2. Peran informasi (Informational Role)

Dalam organisasinya, pimpinan berfungsi sebagai pusat informasi. Dikarenakan kontak interpersonalnya, baik dengan bawahan maupun dengan jaringan kontaknya yang lain, seorang pemimpin muncul sebagai pusat syaraf bagi unit organisasinya. Pemimpin bisa saja tidak tahu segala hal, tapi setidaknya tahu lebih banyak daripada stafnya. Pemrosesan informasi merupakan bagian utama dari tugas seorang pimpinan. la mengembangkan pusat informasi bagi kepentingan organisasinya. Peran pimpinan sebagai peran informasi yang terdiri peran sebagai monitor, peran penyebar, maupun peran sebagai juru bicara. Untuk peran monitor pada Badan Pelayanan Perizinan Terpadu belum pernah mengalami kasus berat berdasarkan keluhan yang disampaikan masyarakat untuk instansi.

Peran monitor pimpinan dengan memantau kebutuhan sumber daya manusia yang ada pada Badan Pelayanan Perizinan Terpadu Kota Banjarbaru, artinya pimpinan mengatasi permasalahan yang sedang dihadapi. Dalam menghadapi kasus, permasalahan maupun kendala yang membutuhkan pendapat atau saran dari bawahan. Pimpinan tidak akan segan meminta atau mengkonfirmasinya.

Dalam perannya sebagai penyebar, pimpinan menerima dan menghimpun informasi dari luar yang penting artinya dan bermanfaat bagi organisasi. Sebagian besar informasi yang diperoleh pimpinan 
harus dimanfaatkan bersama dan didistribusikan kepada bawahan yang membutuhkan. Peran penyebar yang dilakukan pimpinan seperti informasi pengadaan pelatihan dan pendidikan bawahan. Pimpinan memberikan informasi dan rekomendasi kepada bawahan untuk mengembangkan pengalamannya dengan mengikuti pelatihan, maupun studi banding ke daerah lain.

Untuk peran sebagai juru bicara, pimpinan memanfaatkan informasi yang didapatkan untuk dengan menjalin kerjasama dengan pihak luar seperti organisasi swata maupun pengusaha dalam hal ini bidang perizinan. Mendapat masukan atau menjalin kerjasama yang dibutuhkan untuk kemajuan instansi.

3. Peranan memutuskan

Seorang pimpinan memegang peran yang sangat penting dalam sistem pengambilan keputusan dalam organisasinya. Informasi yang diperoleh pimpinan bukanlah tujuan akhir, tetapi merupakan masukan dasar bagi pengambilan keputusan. Pimpinan yang mampu menggunakan gaya partisipatif dengan kepercayaan penuh antara pimpinan dan bawahan maka tidak ada keraguan dalam pengambilan keputusan. Pengambilan keputusan yang dilakukan bersifat luas. Dengan memantapkan informasi lengkap yang sudah dimiliki sebelumnya, ditambah dukungan dari semua bidang tentunya pengambilan keputusan akan lebih akurat. Sistem kepercayaan yang diberikan bawahan kepada atasan untuk mengambil keputusan penting seharusnya memang sudah sangat layak dilakukan, karena pimpinanlah yang bertanggungjawab menjalankan organisasi.

Peran memutuskan yang dijalankan pimpinan seperti melakukan inovasi terhadap pelayanan perizinan. Seperti untuk perizinan usaha kecil dan menengah (UKM) hanya memerlukan waktu 4 (empat) hari saja. Dan juga Badan Pelayanan Perizinan Terpadu membuat terobosan pembuatan izin yang diberi nama "Izin Paket". Keputusankeputusan tepat yang diambil pimpinan member dampak yang baik, salah satunya mampu menciptakan proses perizinan yang capat, responsif dan tidak berbelit, hal ini akan menciptakan kemudahan bagi para pengusaha untuk mendirikan suatu usaha atau investor yang hendak berivestasi di Kota Banjarbaru.

Terbentuknya website resmi sendiri, setelah sebelumnya bergabung dengan website Kota Banjarbaru. pimpinan juga mulai mencoba mengembangkan sistem pelayanan perizinan secara online, artinya para pemohon izin tidak perlu datang ke kantor Badan Pelayanan Perizinan Terpadu Kota
Banjarbaru, cukup mengupload dokumen-dokumen yang dibutuhkan ke website Badan Pelayanan Perizinan Terpadu Kota Banjarbaru dan di dalam website tersebut sudah dilengkapi petunjuk manual permohonan izin secara online.

Sehingga pada pembahasan dari hasil penelitian, diambil proposisi sebagai berikut :

1. Interaksi yang dilakukan pimpinan kepada bawahan dengan menggunakan gaya komunikasi pimpinan partisipatif dalam menyampaikan informasi maupun pesan mampu meningkatkan motivasi bawahan dalam pelayanan publik.

2. Gaya komunikasi pimpinan yang diterapkan kepada bawahan mendapat dukungan penuh didalam organisasi pelayanan publik sehingga tujuan organisasi dapat dicapai.

3. Kemampuan pimpinan dalam mengemban tugas memimpin dan menjalankan organisasiberpengaruh terhadap keberhasilan pelayanan publik.

\section{KESIMPULAN DAN SARAN \\ KESIMPULAN}

Berdasarkan hasil wawancara, kajian pustaka dan observasi yang dilakukan dapat diambil kesimpulan sebagai berikut:

1. Gaya komunikasi kepemimpinan dengan menggunakan teori empat system Likert maka ditarik kesimpulan bahwa pimpinan menggunakan gaya partisipatif. Dalam hal ini pimpinan mempunyai kepercayaan yang sempurna terhadap bawahannya. Dalam setiap persoalan, selalu mengandalkan untuk mendapatkan ide-ide dan pendapat-pendapat lainya dari bawahan, dan mempunyai niatan untuk mempergunakan pendapat bawahan secara konstruktif. Memberikan penghargaan yang bersifat ekonomis, dengan berdasarkan partisipasi kelompok dan keterlibatannya pada setiap urusan terutama dalam penentuan tujuan bersama dan penilaian kemajuan pencapaian tujuan terebut. Pimpinan juga mau mendorong bawahan untuk ikut bertanggung jawab membuat keputusan, dan juga melaksanakan keputusan tersebut dengan tanggung jawab yang besar. Bawahan merasa secara mutlak mendapat kebebasan untuk membicarakan sesuatu yang berkaitan dengan tugasnya kepada pimpinan. Perilaku pimpinan kepada bawahan berorientasi pada tugas (The Job Centered) juga berorientasi pada bawahan (The Employee Centered). Pimpinan akan mengarahkan dan mengawasi bawahannya agar sesuai dengan 
yang diharapkan. Perilaku pimpinan ini mengutamakan keberhasilan dari pekerjaan yang hendak dicapai daripada perkembangan kemampuan bawahannya. Pimpinan juga berusaha mendorong dan memotivasi pekerjaan bawahan untuk bekerja dengan baik. Mereka mengikutsertakan pekerjaannya dalam mengambil suatu keputusan. Pimpinan juga berusaha mendorong bawahan agar meningkatkan pendidikan dan pengalaman dengan mengikutsertakan dalam diklat maupun kunjungan-kunjungan. Kemampuan bawahan juga didukung dengan pemberian motivasi dan pendidikan yang mendukung kinerja mereka.

2. Peran komunikasi pimpinan terhadap bawahan dalam meningkatkan pelayanan prima berdasarkan teori Mintzberg berjalan baik dilihat dari dimensi peran interpersonal, informasi, dan peran pengambilan keputusan. Pimpinan menggunakan peran yang diberikan dengan baik, selalu berusaha mengkomunikasikan masalah dan mencari pemecahan masalah yang ada bersama-sama.

\section{SARAN}

Adapun saran yang dapat diberikan, sebagai berikut:

\section{Saran Akademik}

Dalam penelitian ini hanya membahas tentang gaya komunikasi kepemimpinan menggunakan teori Likert. Peran komunikasi pimpinan kepada bawahan menggunakan teori Mintzberg. Selain kedua teori tersebut masih banyak teori lain yang berhubungan dengan komunikasi organisasi, kepemimpinan, maupun pelayanan publik. Dan masih banyak hal lain yang mungkin belum dibahas pada penelitian ini. Untuk itu disarankan pada penelitian selanjutnya agar dapat mengembangkan penelitian dengan menambahkan aspek-aspek lainnya.

Ataupun teori lain untuk memperkaya penelitian yang ada hubungannya dengan komunikasi organisasi, kepemimpinan dan pelayanan publik. Dan apabila memungkinkan, untuk penelitian selanjutnya mengambil informan dari pihak bawahan agar dapat diketahui penilaian atau hasil yang lebih akurat tentang hubungan pimpinan dan bawahan.

\section{Saran Praktis}

1) Pimpinan sebaiknya tetap mempertahankan gaya komunikasi kepemimpinan yang sudah ada, namun gaya tersebut disesuaikan dengan situasi yang ada pada lingkungan kerja.
2) Pimpinan diharapkan dapat mempertahankan kondisi motivasi kerja karyawan dengan menciptakan kebersamaan antar bawahan, seperti rekreasi bersama atau olah raga bersama, guna menjaga keeratan sesama bawahan maupun pimpinan.

3) Pimpinan sebaiknya memperbaiki cara berkomunikasi dengan baik agar tidak terlihat kaku, sehingga bawahan semakin tidak canggung dan proses komunikasi dapat berjalan lebih lancar.

\section{DAFTAR PUSTAKA}

[1] Ruslan, Rosady. 2010. Metode Penelitian Public Relations dan Komunikasi. Jakarta: PT. Raja Grafindo Persada. 83

[2] Effendy.Onong Uchjana. 2011. IImu Komunikasi;Teori dan Praktik. Bandung: Remaja Rosdakarya. 115

[3] Griffin, Em, 2003, A First Look At Communication Theory, McGraw Hill.

[4] Reza Regina. 2010. Pengaruh Gaya Kepemimpinan. Motivasi. 15

[5] Sugiyono. 2011. Metode Penelitian Kuantitatif Kualitatif Dan $R \& D$. Bandung : Alfabeta. 216

[6] Soesanto, Slamet, 2001, Administrasi Kantor Manajemen dan Aplikasi, Jakarta: Djambatan. 84

[7] Mulyana, Deddy, 2010, Ilmu Komunikasi: Teori Dan Praktek, Bandung, Remaja Rosdakarya. 28

[8] Arni.M. (2011). Komunikasi Organisasi. Edisi Dua Belas. Jakarta: PT. Bumi Aksara. 116

[9] Pace, Wayne \& Faules, Don. 2010. Komunikasi Organisasi. : Strategi Meningkatkan Kinerja Perusahaan.Bandung : PT Remaja Rosdakarya. 190

[10] Darmiyanti Zuchdi. (2011). Pendidikan Karakter Dalam Perspektif Teori Dan Praktik. Yogyakarta: UNY Press. 141

[11] West, Richard dan LYNN h. Turner. 2008. Pengantar Teori Komunikasi; Analisis Dan Aplikasi. Buku 1 Edisi ke-3. Terjemahan. Maria Natalia Damayanti Maer. Jakarta; Salemba Humanika. 105

[12] Winardi.J. (2012). Manajemen Perilaku Organisasi. Edisi Keempat. Jakarta: Kencana. 6 